\title{
Comparison of Primary and Delayed Ureteroscopy for Ureteric Stones: A Prospective Non-Randomized Comparative Study
}

\author{
Alastair Mckay ${ }^{a}$ Bhaskar K. Somani ${ }^{b, c}$ Amelia Pietropaolob Robert Geraghty ${ }^{b}$ \\ Lily Whitehurst $^{\mathrm{b}}$ Rena Kyriakides ${ }^{\mathrm{b}}$ Omar M. Aboumarzouk ${ }^{\mathrm{a}}$ \\ aDepartment of Urology, Queen Elizabeth University Hospital, Glasgow, UK; 'b Department of Urology, \\ University of Hospital Southampton NHS Trust, Southampton, UK; ' University of Southampton, Southampton, UK
}

\section{Keywords}

Primary ureteroscopy · Delayed ureteroscopy · Immediate ureteroscopy · Ureteric stones - Emergency ureteroscopy

\begin{abstract}
Background: Primary ureteroscopy (P-URS) has been shown to be as safe and as efficacious as preoperative stent insertion followed by a delayed ureteroscopy (D-URS). However, studies are of limited patient cohort. Methods: A prospective study comparing P-URS and laser fragmentation for ureteric stones to those who received a stent insertion followed by D-URS and stone fragmentation. Results: A total of 367 consecutive patients were included. P-URS was conducted on 235 patients and D-URS on 132 patients. There was no overall difference between patient or stone demographics between the 2 groups, although there were more proximal ureteric and pelvi-ureteric junction stones in the preoperative stent group. The mean operative times were comparable with a stone free rate of 97 and $94 \%$ in the preoperative stent and no-stent groups, respectively. The overall complication rates were comparable. Conclusion: The current study provides evidence for the feasibility, safety, and efficacy of P-URS for ureteric calculi in a publicly funded healthcare setting with
\end{abstract}

karger@karger.com www.karger.com/uin

Karger $\stackrel{\text { ' }}{5}$

GOPEN ACCESS
(C) 2020 The Author(s)

Published by S. Karger AG, Basel

This article is licensed under the Creative Commons AttributionNonCommercial-NoDerivatives 4.0 International License (CC BY NC-ND) (http://www.karger.com/Services/OpenAccessLicense). Usage and distribution for commercial purposes as well as any distribution of modified material requires written permission. results comparable to those patients with a preoperative stent and delayed procedure. Therefore, cumulatively, P-URS could lead to less hospitalization, length of stay, stent-related morbidity, and ultimately will be more cost-effective.

(c) 2020 The Author(s)

Published by S. Karger AG, Base

\section{Introduction}

The lifetime prevalence of urolithiasis (renal and ureteric stones) is around 14\% and rising [1]. In England, there has been a $70 \%$ increase in the number of hospital episodes related to urolithiasis between 2000 and 2015 (from 51,035 to 86,742 episodes) [1]. As a result, the cost of managing urolithiasis is also increasing, from direct costs of investigation and treatment to indirect costs of medical follow-up appointments, absence from work, and reduced quality of life.

Traditionally, primary management of a ureteric colic episode has taken the form of temporising measures such as analgesia, expectant or delayed management, and/or primary ureteric stent or nephrostomy insertion. However, all of these measures can result in the patient returning to hospital with further symptoms or appointments 
Table 1. Patient factors

\begin{tabular}{|c|c|c|c|}
\hline $\begin{array}{l}\text { URS for ureteral stones } \\
(n=367)\end{array}$ & $\begin{array}{l}\text { Preoperative stent } \\
\text { (D-URS group) }(n=132)\end{array}$ & $\begin{array}{l}\text { No preoperative stent } \\
\text { (P-URS group) }(n=235)\end{array}$ & $\begin{array}{l}p \text { value } \\
(95 \% \mathrm{CI})[\text { test }]\end{array}$ \\
\hline Mean age, years & $55.92 \pm 19.11$ & $55.83 \pm 19.71$ & $\begin{array}{l}0.97(-4.27 \text { to } 4.04) \text { [independent } t \\
\text { test] }\end{array}$ \\
\hline Gender, $n$ & $\begin{array}{l}\text { M: } 82 \\
\text { F: } 50\end{array}$ & $\begin{array}{l}\text { M: } 166 \\
\text { F: } 69\end{array}$ & $0.085\left[\chi^{2}\right]$ \\
\hline Mean cumulative stone size, $\mathrm{mm}$ & $9.01 \pm 4.36$ & $8.87 \pm 4.79$ & $\begin{array}{l}0.79(-1.18 \text { to } 0.90) \text { [independent } t \\
\text { test] }\end{array}$ \\
\hline Mean number of stones & $1.06 \pm 0.30$ & $1.09 \pm 0.33$ & $\begin{array}{l}0.42(-0.04 \text { to } 0.10) \text { [independent } t \\
\text { test] }\end{array}$ \\
\hline Ureteric stone location, $n(\%)$ & $\begin{array}{l}\text { VUJ: } 8(6.1) \\
\text { Distal: } 26(19.7) \\
\text { Mid: } 23(17.4) \\
\text { Proximal: } 33(25) \\
\text { PUJ: } 39 \text { (29.5) } \\
\text { Ureteric not-specified: } 3 \text { (2.3) }\end{array}$ & $\begin{array}{l}\text { VUJ: } 32(13.6) \\
\text { Distal: } 55(23.4) \\
\text { Mid: } 41(17.4) \\
\text { Proximal: } 54(23.0) \\
\text { PUJ: } 46 \text { (19.7) } \\
\text { Ureteric not-specified: } 7 \text { (3.0) }\end{array}$ & $0.11\left[\chi^{2}\right]$ \\
\hline
\end{tabular}

PUJ, pelvi-ureteric junction; VUJ, vesico-ureteric junction; P-URS, primary ureteroscopy; D-URS, delayed ureteroscopy.

and, thus, exacerbating the burden of urolithiasis on both the individual and healthcare system.

Increasingly, a clinical and financial argument is being made for expediting definitive management of ureteric stones, with primary ureteroscopy (P-URS) offering one such option $[2,3]$. A number of studies have looked at the role of P-URS [4], but published data from the UK or other public healthcare-dominated systems, where emergency admissions contribute a significant element to the overall volume of work, are limited. The present non-randomized, cohort study aimed to assess the efficacy and safety of primary and delayed ureteroscopic management of ureteric stones.

\section{Methods}

Between 2016 and 2018, 367 consecutive patients were included, in a prospective manner, who were diagnosed with an acute ureteric calculus $>3 \mathrm{~mm}$ in size requiring intervention. Indications for intervention included refractory pain, obstructive acute kidney injury, or stone location and/or size which was deemed to be unfavourable for conservative management. The patients then underwent primary or delayed ureteroscopy (D-URS). All patients allocated to D-URS were managed initially with ureteric stenting, and this was based on the initial presentation, surgeon expertise, and if the patient was referred from a peripheral hospital.

The intuitional review board approved the study. The study was conducted in accordance with the International Conference on Harmonization guidelines for Good Clinical Practice and the Declaration of Helsinki (September 2018).

Comparison of Primary versus Delayed

Ureteroscopy for Ureteric Stones
All patients underwent a diagnostic non-contrast CT scan to define the size, number, and site of any ureteric stones. Stone position was classified as pelvi-ureteric junction, proximal-ureter, mid-ureter, distal-ureter, vesico-ureteric junction, or not specified.

All procedures were performed within a single centre by either a consultant urologist (BKS) or a urology senior fellow under close supervision. Ureteroscopy was performed under general anaesthesia with intravenous antibiotics given on induction. A 4.5/6.0-Fr semi-rigid ureteroscope (Storz or Wolf) was used with a Storz Flex X2 flexible ureterorenoscope (Karl Storz Endoscopy [UK] Ltd., Slough, UK) available if required. Any stone fragmentation required was performed with a Holmium: YAG laser $(20 \mathrm{~W} / 100 \mathrm{~W}$, Lumenis [UK] Ltd., Elstree, UK) and a $272-\mu \mathrm{m}$ laser fibre (Lumenis, Inc.). Stone fragments were removed with a 1.7-Fr Cook NGage ${ }^{\circledR}$ nitinol stone extractor (Cook Medical, Bloomington, IN, USA). The decision to place a ureteric stent following the procedure was left to the operating surgeon's discretion. Duration of procedure was noted.

Stone free status was defined as complete endoscopic intra-ureteric stone clearance with no residual stone fragments left. Postoperative stone free status was determined by plain X-ray KUB for radio-opaque stones. Ultrasound scan or CT scan was performed 6-12 weeks after the procedure and was defined as complete stone clearance. Length of stay and any postoperative complications were noted.

Data were analysed using SPSS version 16.0 (SPSS, Chicago, IL, USA). Categorical data were assessed using $\chi^{2}$ and Fisher's exact test. Continuous data were analysed using the independent $t$ test with the assumption that the data were normally distributed. Statistical significance level was set at 0.05 . 
Table 2. Operative outcomes

\begin{tabular}{|c|c|c|c|}
\hline Mean operative time, min & $38.33 \pm 22.05$ & $37.36 \pm 21.46$ & 0.69 ( -5.70 to 3.76 ) [independent $t$ test] \\
\hline Stone free, $n(\%)$ & $\begin{array}{l}\text { Yes: } 128(97.0) \\
\text { No: } 4(3.0)\end{array}$ & $\begin{array}{l}\text { Yes: } 219(93.6) \\
\text { No: } 15(6.4)\end{array}$ & $0.22[\mathrm{FET}]$ \\
\hline Postoperative stent, $n(\%)$ & $101(78.3)$ & $179(78.2)$ & $0.98[\chi 2]$ \\
\hline Mean length of stay, days & $0.80 \pm 2.62$ & $0.78 \pm 4.29$ & 0.97 ( -0.82 to 0.79 ) [independent $t$ test] \\
\hline \multirow[t]{2}{*}{ Complications, $n(\%)$} & $\begin{array}{l}\text { No: } 127 \text { (96.2) } \\
\text { Yes: } 5 \text { (3.8) }\end{array}$ & $\begin{array}{l}\text { No: } 226(97) \\
\text { Yes: } 7 \text { (3) }\end{array}$ & $0.98\left[\chi^{2}\right]$ \\
\hline & $\begin{array}{l}\text { Stent pain }-1 \\
\text { UTI }-2 \\
\text { Pneumonia }-1 \\
\text { Sepsis - } 1\end{array}$ & $\begin{array}{l}\text { Stent pain }-4 \\
\text { Haematuria needing catheter irrigation }-1 \\
\text { UTI - } 2\end{array}$ & \\
\hline
\end{tabular}

P-URS, primary ureteroscopy; D-URS, delayed ureteroscopy.

\section{Results}

\section{Patient Factors}

A total of 367 consecutive patients were included in the study. Of these, P-URS was performed on 235 (64\%) patients, and $132(36 \%)$ patients underwent D-URS following primary ureteric stent insertion. The mean age of patients in the P-URS group was 55.83 (SD 19.71) compared to 55.92 (SD 19.11) in the D-URS group. There was a similar spread of male and female patients in both groups. P-URS group had 166 male patients (70\%) compared to 82 male patients $(62 \%)$ in the D-URS group $(p=0.085)$ (Table 1$)$.

\section{Stone Outcomes}

Mean number of stones in the D-URS group was 1.06 (SD 0.30) and 1.09 (SD 0.33) in the P-URS group ( $p=$ 0.42 ). Mean cumulative stone size $(\mathrm{mm})$ was 9.01 (SD 4.36 ) in the D-URS group and 8.87 (SD 4.79) in the PURS group $(p=0.79)$. There was no significant difference between groups in stone location $(p=0.11)$ with proximal location being the most common location in both groups, with $54.5 \%$ of stones in the D-URS group lying in either the pelvi-ureteric junction or the proximal ureter, and $42.7 \%$ in the P-URS group (Table 1).

\section{Operative Outcomes}

Mean operative time (min) in the D-URS group was 38.33 (SD 22.05) and 37.36 (SD 21.46) in the P-URS group $(p=0.69)$. There was no significant difference between the groups in the decision to leave a postoperative stent $(p=0.98)$.

There was only 1 procedure failure in either group, which occurred in the P-URS group. In this case, a proximal ureteric stone had become impacted and a ureteric stent had to be inserted before the patient returned for secondary procedure (Table 2 ).

\section{Postoperative Outcomes}

Mean length of stay (days) in the D-URS group was 0.80 (SD 2.62) and 0.78 (SD 4.29) in the P-URS group $(p=0.97)$. There was no significant difference between the groups in terms of stone free rates (SFR) $(p=0.22)$ with $97 \%$ SFR in the D-URS group and $93.6 \%$ SFR in the P-URS group.

Complications were identified in 12 patients, 5 in the D-URS group (3.8\%) and 7 in the P-URS group (3.0\%) $(p=0.98)$. All complications are listed in Table 1. All complications were deemed minor as no complication was above Clavien-Dindo grade 2 [5] (Table 2).

\section{Discussion}

In this prospective, non-randomized comparative study, we found that there was no significant difference in either intraoperative or postoperative outcomes between D-URS following initial ureteric stent insertion and P-URS. No significant differences were seen in op- 
erative times, utilization of postoperative stenting, stone free rates, or complications. This is in concordance with a recent cumulative analysis of studies looking at emergent versus delayed treatment for ureteric stones [4].

As far as the authors are aware, this is the first published UK data comparing primary and D-URS. Despite this, the data support the recent updated UK guidance from the National Institute of Clinical Excellence [2] which recommends that clinicians "offer surgical treatment to adults with ureteric stones and renal colic within $48 \mathrm{~h}$ of diagnosis or readmission if pain is ongoing or the stone is unlikely to pass."

Data from other public healthcare systems [6] have been published showing that emergency ureteroscopy is feasible. This single-centre case series showed that within the confines of a publicly funded, tertiary referral centre, a large proportion (79\%) of ureteroscopy for acute ureteric calculi can be performed in an emergency setting. The success rates in our series were greater in both cohorts (D-URS 97\% and P-URS 93.6\%) compared to 72\%. The authors conceded that they utilized a fairly conservative approach with low utilization of flexible ureteroscopy to pursue migrated or residual fragments (60\% SFR for proximal stones), which may explain the difference in success rates. Availability of staff with a sub-speciality interest in stone surgery may also have influenced our high stone free rates. Our stone free rate also compared favourably to other emergency ureteroscopic management studies (89-98\%) [7-10].

Overall postoperative complication rates were not significantly different between groups (D-URS 3.8\% and PURS 3.0\%) and are similar to those reported in larger studies of ureteroscopy [11]. Others have reported higher complication rates of $11.8 \%$ [7] and $13.1 \%$ [10] in emergent ureteroscopy, but notably, both these studies utilized pneumatic stone fragmentation rather than laser.

There were no cases of failed access in either group, which remains a risk in P-URS. The operative times between the groups were also not significantly different (DURS $=38 \mathrm{~min}$ and $\mathrm{P}$-URS $=37 \mathrm{~min}$ ). There is discordance in the literature regarding the benefits and risks of preoperative stenting for renal and ureteric calculi. A recent meta-analysis by Wang et al. [12] found that ureteric stents are associated with longer operating times and lower stone free rates in ureteroscopy for ureteric calculi.

There was a single case of failure to complete that occurred in the P-URS group due to an impacted proximal ureteric stone. Operative decision-making in those patients with obstructing ureteric calculi remains an important subgroup. Some [13] have suggested a scoring system

Comparison of Primary versus Delayed

Ureteroscopy for Ureteric Stones that incorporates factors that may influence the likelihood of success (periureteral density and change in serum $\mathrm{Cr}$ from baseline) as a way of risk-stratifying patients. The same authors also found that the administration of alphablockers preoperatively may improve success rates.

The popularity of ureteroscopy is increasing worldwide [14]. With the according increase in skills and familiarity with endourological approaches to stone management, it is perhaps a natural progression to offer ureteroscopy in a primary or emergency setting. The main drawback to this approach may be that the use of more conservative treatment is reduced, particularly in the context of decreasing use of shockwave lithotripsy [15] and evidence over the efficacy of medical expulsion therapy [16]. Parallels can be drawn with similar developments in gallbladder surgery where the initial move to offering immediate surgery [17] has now been tempered with calls to be more restrictive due to a risk of overtreatment [18].

A recent study from the USA [19] found that patients with acute renal colic treated with early endoscopic removal had a higher predicted probability of filing a shortterm disability claim (16.5 vs. $6 \%)$ and had more one more day of absence from work ( 2 vs. 1 day) compared to those patients managed conservatively. However, conservative management was medical expulsive therapy rather than interim ureteric stenting.

Although the data were prospectively collected, it was retrospectively analysed leaving room for confirmation bias. Some additional factors that would have been useful to know were also missing from the analysis, namely, a measure of the patient's comorbidity, via the Charleston Comorbidity Index or ASA category, although the spread of age across the groups was not significantly different. The study was non-randomized leaving scope for allocation bias from the operating surgeon. However, the mean operative durations between the groups were not significantly different suggesting that those allocated to P-URS were not any more or less technically demanding.

HES data $[20,21]$ reveal that over a 10 -year period, there has been a moderate $5 \%$ increase in emergency admissions related to urolithiasis $(30,437$ in 2006-2007 compared to 31,943 in 2016-2017). Correspondingly, there has been much larger (21\%) growth in total episodes related to urolithiasis (77,868 in 2006-2007 compared to 94,796 in 20162017). It is possible that the delayed approach to management of ureteric calculi, which may generate additional outpatient clinic appointments as well as an elective theatre appointment, has contributed to this more significant rise.

The present study did not look at the cost-effectiveness of primary versus delayed ureteroscopic intervention. 
However, it would not be unreasonable to assume that immediate stone removal rather than delayed management with an interval ureteric stent would result in a reduction in stent-related patient morbidity and further generated healthcare episodes. The challenge for urologists, particularly in a publicly funded healthcare system, will be in delivering this model of care. Obstacles may include access to emergency theatres, theatre staff skills, theatre facilities, and surgical endourological experience.

\section{Conclusion}

The current study provides evidence for the feasibility, safety, and efficacy of P-URS for ureteric calculi in a publicly funded healthcare setting with results comparable to those patients with a preoperative stent and delayed procedure. Therefore, cumulatively, P-URS could lead to less hospitalization, length of stay, stent-related morbidity, and ultimately will be more cost-effective.

\section{Statement of Ethics}

Our audit was registered with the local audit committee, and the patients were consented for outcome research.

\section{Conflict of Interest Statement}

The authors have nothing to disclose.

\section{Funding Sources}

The authors declare no sources of funding or conflicts of interest.

\section{Author Contributions}

O.M.A. and B.K.M. conceived the presented idea. O.M.A. supervised the work. A.C.M., A.P., R.G., L.W., and R.K. collected and analysed the data. A.C.M. wrote the manuscript, and all other authors reviewed it.

\section{References}

1 Rukin NJ, Siddiqui ZA, Chedgy ECP, Somani BK. Trends in upper tract stone disease in England: evidence from the hospital episodes statistics database. Urol Int. 2017;98(4):3916.

2 NICE. Renal and ureteric stones: assessment and management. NICE; 2019 Jan.

3 Türk C, Skolarikos A, Neisius A, Seitz C, Skolarikos A, Thomas K, et al. EAU guidelines on urolithiasis. Arnhem, The Netherlands: EAU Guidelines Office; 2019.

4 Arcaniolo D, De Sio M, Rassweiler J, Nicholas J, Lima E, Carrieri G, et al. Emergent versus delayed lithotripsy for obstructing ureteral stones: a cumulative analysis of comparative studies. Urolithiasis. 2017;45(6):563-72.

5 Dindo D, Demartines N, Clavien PA. Classification of surgical complications: a new proposal with evaluation in a cohort of $6336 \mathrm{pa}-$ tients and results of a survey. Ann Surg. 2004; 240(2):205-13.

6 Zargar-Shostari K, Anderson W, Rice M. Role of emergency ureteroscopy in the management of ureteric stones: analysis of 394 cases. BJU Int. 2015;115(6):946-50.

7 Sarica K, Tanriverdi O, Aydin M, Koyuncu H, Miroglu C. Emergency ureteroscopic removal of ureteral calculi after first colic attack: is there any advantage? Urology. 2011;78(3): $516-20$.

8 Guerico S, Ambu A, Mangione F, Mari M, Vacca F, Bellina M. Randomized prospective trial comparing immediate versus delayed ureteroscopy for patients with ureteral calcu- li and normal renal function who present to the emergency department. J Endourol. 2011; 25(7):1137-41.

9 Youn JH, Kim SS, Yu JH, Sung LH, Noh CH, Chung JY. Efficacy and safety of emergency ureteroscopic management of ureteral calculi. Korean J Urol. 2012;53(9):632-5.

10 Matani YS, Al-Ghazo MA, Al-Azab RS, Hani OB, Ghalayini IF, Hani IB. Emergency versus elective ureteroscopic treatment of ureteral stones. Can Urol Assoc J. 2013;7(7-8):E4704.

11 de la Rosette J, Denstedt J, Geavlete P, Keeley F, Matsuda T, Pearle M, et al. The clinical research office of the endourological society ureteroscopy global study: indications, complications, and outcomes in 11,885 patients. J Endourol. 2014;28(2):131-9.

12 Wang H, Man L, Li G, Huang G, Liu N, Wang J. Meta-analysis of stenting versus non-stenting for the treatment of ureteral stones. PLoS One. 2017;12(1):e0167670.

13 Tran TY, Hernandez Bustos N, Kambadakone A, Eisner B, Pareek G. Emergency ureteral stone treatment score predicts outcomes of ureteroscopic intervention in acute obstructive uropathy secondary to urolithiasis. J Endourol. 2017;31(9):829-34.

14 Wright AE, Rukin NJ, Somani BK. Ureteroscopy and stones: current status and future expectations. World J Nephrol. 2014;3(4):2438.

15 Geraghty RM, Jones P, Somani BK. Worldwide trends of urinary stone disease treat- ment over the last two decades: a systematic review. J Endourol. 2017;31(6):547-56.

16 Pickard R, Starr K, MacLennan G, Lam T, Thomas R, Burr J, et al. Medical expulsive therapy in adults with ureteric colic: a multicentre, randomised, placebo-controlled trial. Lancet. 2015;386(9991):341-9.

17 da Costa DW, Bouwense SA, Schepers NJ, Besselink MG, van Santvoort HC, van Brunschot $\mathrm{S}$, et al. Same-admission versus interval cholecystectomy for mild gallstone pancreatitis (PONCHO): a multicentre randomised controlled trial. Lancet. 2015; 386(10000):1261-8.

18 van Dijk AH, Wennmacker SZ, de Reuver PR, Latenstein CSS, Buyne O, Donkervoort $\mathrm{SC}$, et al. Restrictive strategy versus usual care for cholecystectomy in patients with gallstones and abdominal pain (SECURE): a multicentre, randomised, parallel-arm, noninferiority trial. Lancet. 2019;393(10188): 2322-30.

19 Dauw CA, Kaufman SR, Hollenbeck BK, Roberts WW, Faerber GJ, Wolf JS, et al. Expulsive therapy versus early endoscopic stone removal in patients with acute renal colic: a comparison of indirect costs. J Urol. 2014;191(3): 673-7.

20 Hospital Episode Statistics, Admitted patient care - England, 2006-07. Official Statistics. National Statistics. 2007.

21 Hospital Episode Statistics, Admitted patient care - England, 2016-17. Official Statistics. National Statistics. 2017. 